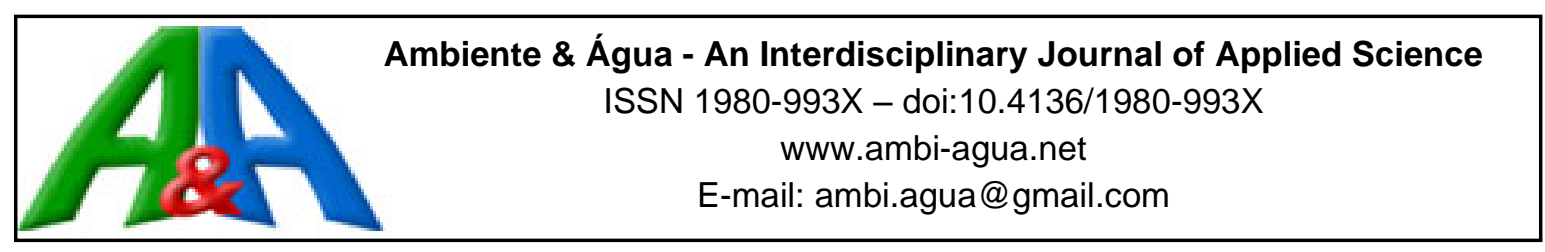

\title{
Arsenic in Santa Catarina soils
}

\author{
ARTICLES doi:10.4136/ambi-agua.2720
}

Received: 08 Mar. 2021; Accepted: 30 Aug. 2021

\author{
Matheus Rodrigo Machado*iD; David José Miquelluti ${ }^{(D)}$; Mari Lucia Campos \\ Centro de Ciências Agroveterinárias. Departamento de Solos e Recursos Naturais. Universidade do Estado de \\ Santa Catarina (UDESC), Avenida Luiz de Camões, n 2090, CEP: 88520-000, Lages, SC, Brazil. \\ E-mail: david.miquelluti@udesc.br, mari.campos@udesc.br \\ *Corresponding author. E-mail: matheus.machado@udesc.br
}

\begin{abstract}
Arsenic (As) is one of the most harmful chemical elements known to man and to the environment, mainly due its high toxicity and wide distribution; the content of this element within the soils is a genuine concern, thus making it paramount to know its natural contents in a regional context. The present study aimed to determine the natural Arsenic content in the A horizon of 31 soil profiles from the state of Santa Catarina, Brazil, which is useful in determining reference values, monitoring, remediation of contaminated areas, legal regulation and Brazilian laws. Soil samples were prepared following the USPEA 3051A SW-846 method and were previously chemically reduced from As(V) to AS(III) by using the BCR method. The determination was performed in an Inductively Coupled Plasma - Optical Emission Spectrometry - Hydride Generation (ICP-OES-HG at cold vapor). Results obtained from the soil groups reveal the materials of basaltic origins as the ones with more As content while those of sediment origins had lesser content. Evaluated soil profiles fit into the following descending order regarding their As content: Latossolos, according to EMBRAPA (Oxisols according to Soil Taxonomy) > Nitossolo (Ultisols, Oxisols (Kandic), Alfisols) > Chernossolos (---) = Cambissolo $($ Inceptisols $)=$ Argissolo $($ Ultisols $)>$ Neossolos (Entisols) .
\end{abstract}

Keywords: arsenic content, reference value, soils, trace element.

\section{Arsênio em solos de Santa Catarina}

\section{RESUMO}

O arsênio (As) é listado como um dos elementos químicos mais nocivos ao homem e ao meio ambiente, devido a sua alta toxidade e por ser amplamente distribuído na crosta terrestre, destaca-se a sua preocupação dos teores deste elemento em solos, sendo de suma importância conhecer os teores naturais de As no contexto regional. O objetivo do presente estudo foi determinar o teor de arsênio no horizonte A de 31 perfis de solos do estado de Santa Catarina Brasil, podendo este trabalho auxiliar nos valores de referência, monitoramento, remediação de áreas contaminadas, regulamentos e leis brasileiras. As amostras de solos foram preparadas segundo o método USEPA 3051A SW-846 e pré-reduzidos quimicamente do As(V) para As(III) através do método BCR. A determinação foi realizada em Espectrômetro de Emissão Óptica com Plasma Acoplado Indutivamente com Geração de Hidreto. Os resultados obtidos dentre o conjunto de solos, mostram que o material de origem basáltica, foram os que apresentaram os maiores teores de As e o material de origem de sedimentos com os menores. 
Os perfis de solo se enquadram na decrescente ordem no quesito dos teores de As na seguinte sequência: Latossolos $>$ Nitossolo $>$ Chernossolos $=$ Cambissolo $=$ Argissolo $>$ Neossolos .

Palavras-chave: conteúdo de arsênio, elemento traço, solos, valor de referência.

\section{INTRODUCTION}

Arsenic (As), a semimetal, part of Group 15 of the periodic table, is the twentieth most abundant element on Earth (Roy et al., 2015); thus, studying and monitoring this element due to its extensive distribution over the atmosphere, hydrosphere and biosphere is an important matter. According to the World Health Organization (WHO, 2018), Arsenic is one of the ten high-toxicity chemical elements, responsible for causing great concern to public health. Contamination by As of water sources, be they groundwater or surface water, is a global problem (Xu et al., 2020; Gao et al., 2020), with the natural sources of this element generated by the weathering of rocks, biological activities and volcanic emissions (Alonso et al., 2014); in natural soils, this contamination is mainly due the parent material and weathering degree (Marrugo-Negrete et al., 2017). On the other hand, contamination by anthropogenic sources, i.e. not natural ones, is done by production and usage of herbicides, phosphorus fertilizers, mining, industrial waste/residue and activities related to chemical preservation of timber (Chirenje et al., 2003; Alonso et al., 2014; Roy et al., 2015; Gong et al., 2020). As for the toxicity degree, the inorganic $\mathrm{As}^{3+}$ form $\left(\operatorname{arsine} \mathrm{AsH}_{3}\right.$, arsenate $\mathrm{As}(\mathrm{OH})_{3}$, arsenate $\left.\mathrm{AsO}(\mathrm{OH})_{3}\right)$ is ten times more toxic than the $\mathrm{As}^{5+}$ form (Rosas et al., 2014); both forms are carcinogenic, mutagenic and genotoxic. While in the organic methylated form, such as the case of MMA Monomethylarsonic and DMA Dimethylarsinic, organic As is a hundred times less harmful to health in comparison to its inorganic structures (WHO, 2018). As a result of these factors, even in low concentrations As can promote negative effects to health (ATSDR, 2015; Mandal, 2017) and its accumulation, be it because of agricultural or industrial activities, is worrisome due to a possible transference of this element to wild animals or humans ( $\mathrm{Su}$ and Yang, 2008). In Brazil, there are reports of As-contaminated waters (up to $0.36 \mathrm{mg} \mathrm{L}^{-1}$ ), soils (up to $860 \mathrm{mg} \mathrm{kg}^{-1}$ ) and sediments (up to $3.200 \mathrm{mg} \mathrm{kg}^{-1}$ ) situated in vicinity of industrial or mining areas (De Magalhães and Pfeiffer, 1995; Mirlean and Roisenberg, 2006; Pereira et al., 2009; Alves and Rietzler, 2015).

Soil plays an important role in the environment by acting as a natural buffer, controlling the As transport to other compartments, although with limited adsorption (retention) capacity. In this system, toxicity, mobility, solubility, availability and bioavailability in the soil depend on specific conditions such as $\mathrm{pH}$, redox potential, CEC, competition with other elements in different chemical equilibria, and composition and ionic strength of the soil solution (Qiao et al., 2019). Arsenic is a chalcophile element (Goldschmidt, 1958), therefore its mobility is regulated by its oxidation state (Tarvainen et al., 2013); it can be found in the $\mathrm{As}^{5+}$ form when under oxic conditions (Eh>200 mV; $\mathrm{pH} 5-8)$, and in the $\mathrm{As}^{3+}$ form under anoxic conditions (Mcbride, 1994; Singh et al., 2015). When in the soil solution, under anaerobic conditions, it is found in the $\mathrm{Ca}_{3}\left(\mathrm{AsO}_{4}\right)_{2}, \mathrm{Mg}_{3}\left(\mathrm{AsO}_{4}\right)_{2}$ and $\mathrm{As}_{2} \mathrm{O}_{5}$ forms and, when under anaerobic conditions, in the $\mathrm{As}, \mathrm{As}_{2} \mathrm{~S}_{3}$ and $\mathrm{As}_{2} \mathrm{O}_{3}$ forms (Hayes and Traina, 1998). Another interesting factor is that the behavior of arsenate $\left(\mathrm{AsO}(\mathrm{OH})_{3}\right)$ in the soil is similar to phosphate $\left(\mathrm{PO}_{4}{ }^{3-}\right)$ and vanadate ( $\mathrm{VO}_{4}^{-}$(McBride, 1994; Rosas et al., 2014), as it is adsorbed onto $\mathrm{Fe}$ and $\mathrm{Al}$ oxides, such as non-crystalline aluminosilicates and onto argillo silicates as well, to a lesser extent.

The first studies on natural As contents in soils were by Curi and Franzmeier (1987), with "Latossolos Ferríferos", according to EMBRAPA, (Ferric Oxisols, according to Soil Taxonomy) in Minas Gerais, and Campos et al. (2007), with seventeen "Latossolos" (Oxisols) in Brazil. After publication of the CONAMA 420 Resolution (Conama, 2009), several scientific papers (Pereira et al., 2009; Paye et al., 2010; Campos et al., 2013; De Souza et al., 2016; De 
Menezes et al., 2020) were published with information on natural contents or quality reference values for Brazilian soils.

Determining natural trace element contents in the soil, having no human interference, is necessary for defining quality reference values, monitoring and remediating contaminated areas and, furthermore, contributing in understanding the magnitude of the risks to which the population is exposed to daily (Tsuji et al., 2007).

Considering the above, the advanced agricultural and industrial development of Santa Catarina and its geological and pedological diversity, it is of utmost importance to determine the natural arsenic contents for the soils of the state, which is the objective of the present study.

\section{MATERIAL AND METHODS}

Soils used in this research were collected from the following regions in the state: western area; eastern mountains; Basaltic Slopes; Itajaí Valley; Santa Catarina Mountains; and southern Santa Catarina. Figure 1 illustrates the geographic distribution of the profiles.

\section{Map of the Santa Catarina state, Brazil.}

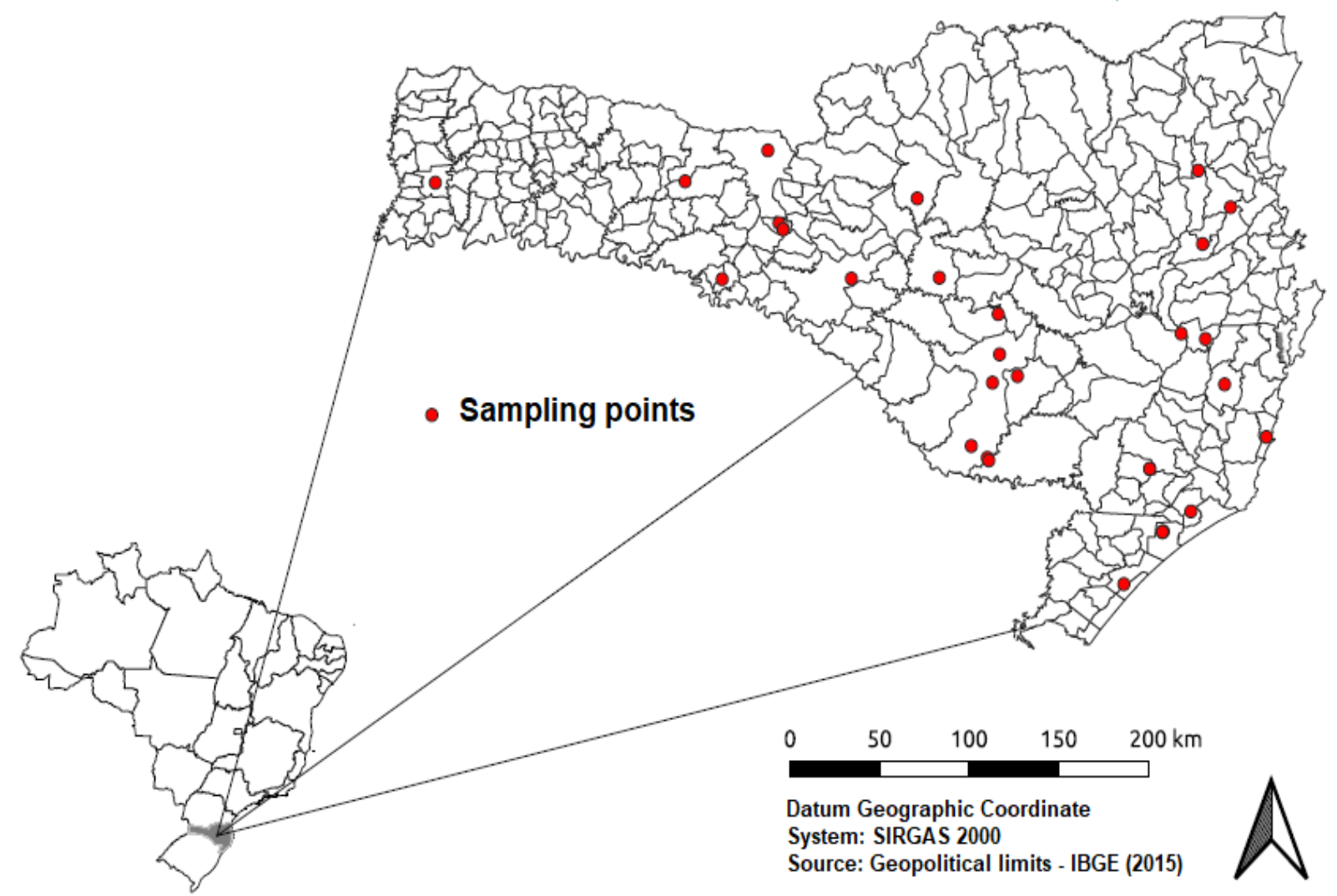

Figure 1. Map with the location of the 31 sample profiles in the Santa Catarina state.

Soil samples are from the A horizons of 31 profiles that were later described and sampled in roadside artificial gully in places under natural vegetation formations of fields or forests. The same authors who performed, described and classified the soils in this study also determined their physical and chemical attributes, described and classified in Table 1. All profiles were described in areas not subjected to anthropogenic arsenic contamination.

Samples were air-dried, had their clods broken, were homogenized and then passed through a sieve with an opening of $2.0 \mathrm{~mm}$. In sequence, they were ground and homogenized in an agate mortar until forming a fine powder and finally sieved at an aperture of $0.297 \mathrm{~mm}$. 
Table 1. Classes, parent material, physical and chemical attributes of evaluated soils.

\begin{tabular}{|c|c|c|c|c|c|c|c|c|c|}
\hline \multirow{2}{*}{ Soil class *EMBRAPA (Soil Taxonomy) } & \multirow{2}{*}{ Lithology } & Sand & Clay & TOC & $\mathbf{T}$ & SB & $\mathbf{V}$ & Al & $\mathbf{F e}$ \\
\hline & & \multicolumn{3}{|c|}{ g kg-1 } & \multicolumn{2}{|c|}{$\mathrm{Cmolc} \mathrm{kg}^{-1}$} & $\%$ & \multicolumn{2}{|c|}{ g kg-1 } \\
\hline Nitossolo Bruno Distrófico típico (Oxisol) & Basalt & 106 & 578 & 34 & 16 & 2.8 & 18 & 46 & 98 \\
\hline Nitossolo Bruno Distrófico rúbrico (Oxisol) & Basalt & 45 & 641 & 46 & 20 & 1.2 & 6 & 41 & 103 \\
\hline Nitossolo Bruno Distroférrico típico (Oxisol) & Andesite basalt & 164 & 446 & 38 & 17 & 4 & 24 & 57 & 165 \\
\hline Nitossolo Bruno Distrófico húmico latossólico rúbrico (Oxisol) & Rhyodacite & 102 & 614 & 33 & 19 & 12 & 62 & 127 & 68 \\
\hline Latossolo Vermelho Distrófico retrático úmbrico (Oxisols) & Basalt & 16 & 774 & 22 & 16 & 1.45 & 9 & 71 & 131 \\
\hline Neossolo Regolítico Húmico típico (Entisol) & Phonolite & 230 & 540 & 30 & 15 & 4.3 & 28 & 156 & 25 \\
\hline Argissolo Bruno-Acinzentado Alítico típico (Ultisol) & Argillites and siltstone & 160 & 320 & 30 & 21 & 2 & 9 & 32 & 16 \\
\hline Argissolo Amarelo Distrófico Típico (Ultisol) & Granite and granulite & 230 & 330 & 35 & 11 & 1.3 & 12 & 44 & 25 \\
\hline Argissolo Vermelho Distrófico abruptico (Ultisol) & Siltstone and Sandstone & 463 & 170 & 15 & 6.2 & 5.2 & 83 & 12 & 14 \\
\hline Argissolo Vermelho-Amarelo Distrófico latossólico (Ultisol) & Sandstone and Siltstone & 718 & 157 & 13 & 5.8 & 2.7 & 47 & 5.8 & 11 \\
\hline Cambissolo Háplico Alumínico úmbrico (Inceptisol) & Rhyodacite & 60 & 580 & 34 & 24 & 1.8 & 7 & 99 & 41 \\
\hline Cambissolo Húmico Distrófico típico (Inceptisol) & Rhyodacite & 192 & 600 & 39 & 19 & 0.9 & 5 & 108 & 44 \\
\hline Nitossolo Vermelho Distroférrico típico (Oxisols) & Basalt & 149 & 590 & 32 & 23 & 10 & 42 & 47 & 116 \\
\hline Cambissolo Háplico Alítico típico (Inceptisol) & Rhyodacite & 99 & 570 & 33 & 23 & 3.7 & 16 & 127 & 39 \\
\hline Argissolo Amarelo Distrófico latossólico (Ultisol) & Migmatito & 290 & 370 & 33 & 9.0 & 2.6 & 26 & 93 & 24 \\
\hline Argissolo Vermelho distrófico (Ultisol) & Siltstone and Sandstone & 680 & 180 & 17 & 6.2 & 5.1 & 83 & 31 & 13 \\
\hline Argissolo Vermelho-Amarelo Distrófico latossólico (Ultisol) & Sandstone and Siltstone & 620 & 300 & 20 & 5.8 & 2.7 & 44 & 5.6 & 12 \\
\hline Nitossolo Bruno Distrófico húmico latossólico rúbrico (Oxisol) & Basalt & 22 & 684 & 38 & 19 & 4.4 & 23 & 102 & 60 \\
\hline Argissolo Vermelho Distrófico abruptico (Ultisol) & Siltstone and Sandstone & 463 & 170 & 15 & 6.2 & 5.2 & 83 & 28 & 17 \\
\hline Argissolo Amarelo Alítico típico (Ultisol) & Mica schists & 530 & 230 & 22 & 16 & 6.4 & 41 & 6.0 & 13 \\
\hline Argissolo Vermelho-Amarelo Alumínico típico (Ultisol) & Metaarenito & 510 & 380 & 27 & 14 & 2.7 & 18 & 7.9 & 10 \\
\hline Argissolo Vermelho-Amarelo Alumínico típico (Ultisol) & Mafic Granulite & 580 & 240 & 25 & 15 & 5.3 & 35 & 7.1 & 14 \\
\hline Chernossolo Argilúvico Férrico típico (---) & Basalt & 220 & 420 & 30 & 20 & 18 & 90 & 34 & 86 \\
\hline Nitossolo Vermelho Eutroférrico típico (Oxisol) & Basalt & 170 & 370 & 51 & 19 & 15 & 79 & 31 & 134 \\
\hline Nitossolo Háplico Distrófico típico (Oxisol) & Basalt & 70 & 670 & 46 & 15 & 7.1 & 46 & 24 & 108 \\
\hline Nitossolo Vermelho Eutrófico típico (Oxisol) & Basalt & 210 & 420 & 28 & 12 & 8.1 & 68 & 11 & 117 \\
\hline Nitossolo Háplico Distrófico típico (Oxisol) & Rhyodacite & 140 & 280 & 33 & 23 & 19 & 83 & 33 & 99 \\
\hline Neossolo Quartzarênico Órtico típico (Entisols) & Sandy sediments & 943 & 36 & 4 & - & 1.3 & - & 3.1 & 1.6 \\
\hline Neossolo Quartzarênico Órtico típico (Entisols) & Sandy sediments & 919 & 58 & 7.4 & - & 1.8 & - & 4.7 & 0.4 \\
\hline
\end{tabular}

$\mathrm{CO}=$ organic carbon by the Walkley-Black method, total organic carbon; $\mathrm{T}$ value $=\mathrm{CEC}$ at $\mathrm{pH} 7.0 ; \mathrm{SB}=\mathrm{Sum}$ of bases; $\mathrm{V}=\mathrm{Base}$ saturation; $\mathrm{Al}$ and Fe obtained by sulfuric attack. Source: based on Almeida et al. (2003), Corrêa (2003), Paes Sobrinho et al. (2009), Bringhenti et al. (2012), Da Costa et al. (2013), Lunardi Neto and Almeida (2013), Teske et al. (2013). 
The USEPA 3051A SW-846 method was employed as the extraction means. For this purpose, $1.5 \mathrm{~g}$ of soil was weighed and $5 \mathrm{~mL}$ of $37 \% \mathrm{HCl} \mathrm{PA} \mathrm{Merck}{ }^{\circledR}$ was added. Samples were in contact with the acid for $12 \mathrm{~h} 00$ and then digested in the microwave (Anton PAAR Multiwave $3000^{\circledR}$ ) inside Teflon tubes. As a form of control and method validation, NIST certified sample SEM 2709A (San Joaquin soil) and reference sample EMBRAPA CRM-Agro E2002a (MR06/2013) were used, and the recovery values are displayed in Table 2.

Table 2. As recovery percentage for SRM 2709A and CRM-Agro E2002a samples.

\begin{tabular}{cccc}
\hline Sample & Recovered content & Certified content & Recovery \\
\hline \multicolumn{3}{c}{$\mathrm{mg} \mathrm{kg}^{-1}$} \\
\hline SRM 2709A & 9.85 & $10.5 \pm 0.3$ & 93.81 \\
CRM-Agro E2002a & 53.38 & $59.3 \pm 7.2$ & 90.02 \\
\hline
\end{tabular}

Soil analyses were performed in the Instrumentation Laboratory of the Department of Soils and Natural Resources from the Centre of Agroveterinary Sciences - UDESC/CAV. Determination of As contents was performed in an Inductively Coupled Plasma Optical Emission Spectrometer Hydride Generator (ICP-OES-HG at cold vapor). Prior to the determination, a chemical pre-reduction step from $\mathrm{As}(\mathrm{V})$ to $\mathrm{As}(\mathrm{III})$ by the BCR method (Varejão et al., 2009) was applied in all samples, adjusting and improving the efficiency in hydride generation. For such, a potassium iodide solution (KI 5\% w/v) and ascorbic acid (5\% $\mathrm{w} / \mathrm{v}$ ), enough to reach $0.2 \% \mathrm{v} / \mathrm{v}$, was added in all samples, in the calibration standard solutions and blank samples. After resting for $12 \mathrm{~h} 00$, As was quantified in ICP-OES-HG at cold vapor (Optima 8300 - Perkin Elmer).

All samples were digested in duplicates and the determination was performed in triplicate per sample. As content readings in the blank samples were used to calculate limits of detection $(\mathrm{LOD})=3 \mathrm{x}$ Standard Deviation (blank samples) / slope of the calibration curve straight line; and limits of quantification (LOQ) $=3.3 \times$ LOD. Obtained values were $0.015 \mathrm{mg} \mathrm{kg}^{-1}$ of LOD and LOQ of $0.050 \mathrm{mg} \mathrm{kg}^{-1}$.

Statistical analyses were performed by using an entirely randomized design separated for each component (Soils, Classes, Parent Material). Comparisons between Soils, Classes, and Parent Material were by employing F and Scott-Knott tests. To meet the theoretical assumptions of these tests, logarithmic transformation of the arsenic content variables was applied as suggested by the descriptive analysis of the data; however, results were presented on the original scale. All analyses were conducted with the R software (R CORE TEAM, 2016). As contents found were also subjected to correlation analysis with the following variables: clay content, silt/clay ratio, organic carbon, sum of bases (SB) and base saturation value (V\%), $\mathrm{Fe}$ and $\mathrm{Al}$ contents by sulfuric attack. For all performed tests, a minimum significance level of $5 \%$ was considered.

\section{RESULTS AND DISCUSSION}

Basalt-derived soils averaged the highest As content $\left(11.59 \mathrm{mg} \mathrm{kg}^{-1}\right)$ while the lowest content was observed on soils derived from sandy sediments $\left(0.82 \mathrm{mg} \mathrm{kg}^{-1}\right)$ (Table 3$)$. Higher contents in soils derived from effusive mafic rocks are related to the presence of higher arsenic contents in rock when compared to the other parent materials of evaluated soils in this study. Arsenic contents in basalt (mafic effusive) vary between 0.18 and $113 \mathrm{mg} \mathrm{kg}^{-1}$ (Mandal and Suzuki, 2002). Arsenic is classified as chalcophile, with basalts and andesites richer in chalcophile elements while granites are poor (Goldschimidt, 1958). $\mathrm{As}^{3+}$ can replace $\mathrm{Fe}^{3+}$ in many rock-forming minerals (Reimann et al., 2009). These As content differences in the rocks 
may explain the low As contents in soils derived from granite, granite-granulite and mafic granite (Table 4).

Table 3. As mean content $\left(\mathrm{mg} \mathrm{kg}^{-1}\right)$ for soils derived from different parent material.

\begin{tabular}{cc}
\hline Parent material & As content \\
\cline { 2 - 2 } & $\mathrm{mg} \mathrm{kg}^{-1}$ \\
\hline Basalt & $11.59 \mathrm{a}$ \\
Siltstone and Sandstone & $10.12 \mathrm{a}$ \\
Argillite and Siltstone & $8.08 \mathrm{a}$ \\
Migmatite & $7.79 \mathrm{a}$ \\
Rhyodacite & $7.72 \mathrm{a}$ \\
Andesite basalt & $7.50 \mathrm{a}$ \\
Metasandstone & $5.84 \mathrm{a}$ \\
Siltstone and Sandstone & $5.36 \mathrm{a}$ \\
Phonolite & $5.06 \mathrm{a}$ \\
Porphyritic phonolite & $3.73 \mathrm{~b}$ \\
Mica schists & $2.84 \mathrm{~b}$ \\
Granite and granulite & $2.77 \mathrm{~b}$ \\
Sandstone and Siltstone & $2.18 \mathrm{~b}$ \\
Mafic granulite & $2.10 \mathrm{~b}$ \\
Granite & $1.42 \mathrm{~b}$ \\
Sandy sediments & $0.82 \mathrm{~b}$ \\
\hline
\end{tabular}

Table 4. Mean As content $\left(\mathrm{mg} \mathrm{kg}^{-1}\right)$ for the main soil orders from Santa Catarina state.

\begin{tabular}{cc}
\hline \multirow{2}{*}{ Order * EMBRAPA (Soil Taxonomy) } & As content \\
\cline { 2 - 2 } & $\mathrm{mg} \mathrm{kg}^{-1}$ \\
\hline Latossolo (Oxisols) & $26.59 \mathrm{a}$ \\
Nitossolo (Ultisols, Oxisols (Kandic), Alfisols) & $10.92 \mathrm{~b}$ \\
Chernossolo (--) & $6.96 \mathrm{c}$ \\
Cambissolo (Inceptisols) & $4.95 \mathrm{c}$ \\
Argissolo (Ultisols) & $4.67 \mathrm{c}$ \\
Neossolo (Entisols) & $1.64 \mathrm{~d}$ \\
\hline
\end{tabular}

The decreasing sequence of As contents was observed in the following soil Orders: Latossolos, according to EMBRAPA (Oxisols according to Soil Taxonomy) > Nitossolo (Ultisols, Oxisols (Kandic), Alfisols) > Chernossolos $(---)=$ Cambissolo (Inceptisols) $=$ Argissolo (Ultisols) $>$ Neossolos (Entisols) (Table 4). The first three orders group soils derived mainly from basic and intermediate magmatic rocks. The soil "Latossolo Vermelho Distrófico retrático úmbrico" (Oxisols), derived from basalt (Serra Geral Formation) and located in Campos Novos (Table 6), had the highest As content $\left(26.59 \mathrm{mg} \mathrm{kg}^{-1}\right)$ of all 31 evaluated soils. Whereas, the "Neossolo Quartzarênico Órtico típico" (Entisols) profile located in Imbituba city, with the original material coming from sandy sediments, had the lowest As content $\left(0.56 \mathrm{mg} \mathrm{kg}^{-1}\right)$.

A natural As content of $31.7 \mathrm{mg} \mathrm{kg}^{-1}$ was found by Campos et al. (2007) for "Latossolo Vermelho Distroférrico típico" (Oxisols) derived from basic and intermediate magmatic rocks of the Serra Geral Formation, and contents of $4.5 \mathrm{mg} \mathrm{kg}^{-1}$ for "Latossolo Amarelo coeso típico" (Oxisols) derived from tertiary sediments. Arsenic content in "Neossolo Quartzarênico órtico típico" (Entisols) collected from the Cerrado, derived from sandstone of Aerado Formation, had $0.28 \mathrm{mg} \mathrm{kg}^{-1}$ (Campos et al., 2013). These results corroborate the observations in this present 
study.

In a predictive modeling study of spatial variability using environmental covariates (contents of organic carbon, clay, sand and $\mathrm{TiO}_{2}$ ) representing the soil formation factors in Brazil, De Menezes et al. (2020) found mean As contents of $11.97 \pm 1.62$ for the Santa Catarina state; however, only six profiles out of the 31 evaluated in the present study demonstrated similar contents.

Natural As contents within the soils "Latossolo Vermelho Distrófico retrático úmbrico" (Oxisols from Campos Novos) of $26.59 \mathrm{mg} \mathrm{kg}^{-1}$ and "Nitossolo Vermelho Eutroférrico típico" (Oxisols from Luzerna) of $17.63 \mathrm{mg} \mathrm{kg}^{-1}$ (Table 5) were higher than the prevention guideline value (15 mg kg${ }^{-1}$ ) established by CONAMA 420 Resolution (Conama, 2009), reinforcing the need for scientific studies that generate guideline values for soils from different Brazilian states. Nevertheless, an important issue is that trace elements in uncontaminated soils have less mobility than trace elements from anthropogenic contamination, because the former are bound to or are part of the structure of minerals, while those from anthropogenic sources may be more available (Botsou et al., 2016). Therefore, natural contents higher than prevention values in soils do not necessarily indicate risks to living beings, due to their lesser availability.

Table 5. As mean content for the main soil profiles in the State of SC.

\begin{tabular}{|c|c|c|}
\hline \multirow{2}{*}{ Soil Class: EMBRAPA (Soil Taxonomy) } & \multirow{2}{*}{ Location } & As Content \\
\hline & & $\mathrm{mg} \mathrm{kg}^{-1}$ \\
\hline Latossolo Vermelho Distrófico retrático úmbrico (Oxisols) & Campos Novos & $26.59 \mathrm{a}$ \\
\hline Nitossolo Vermelho Eutroférrico típico (Oxisols) & Luzerna & $17.63 \mathrm{a}$ \\
\hline Nitossolo Vermelho Distroférrico típico (Oxisols) & Lages & $14.16 \mathrm{a}$ \\
\hline Argissolo Vermelho Distrófico (Ultisols) & Içara & $13.57 \mathrm{a}$ \\
\hline Nitossolo Bruno Distrófico húmico latossólico rúbrico (Oxisols) & Ponte Serrada & $13.19 \mathrm{a}$ \\
\hline Nitossolo Bruno Distrófico húmico latossólico rúbrico (Oxisols) & Curitibanos & $12.45 \mathrm{a}$ \\
\hline Nitossolo Háplico Distrófico típico (Oxisols) & Luzerna & $12.38 \mathrm{a}$ \\
\hline Nitossolo Bruno Distrófico rúbrico (Oxisols & Lebon Régis & $10.96 \mathrm{a}$ \\
\hline Cambissolo Háplico Alítico típico (Inceptisols) & Lages & $10.96 \mathrm{a}$ \\
\hline Nitossolo Vermelho Eutroférrico típico (Oxisols) & Ipira & $9.42 \mathrm{a}$ \\
\hline Cambissolo Húmico Distrófico típico (Inceptisols) & Lages & $9.38 \mathrm{a}$ \\
\hline Argissolo Bruno-Acinzentado Alítico típico (Ultisols) & Alfredo Wagner & $8.08 \mathrm{a}$ \\
\hline Argissolo Amarelo Distrófico latossólico (Ultisols) & São Bonifácio & $7.79 \mathrm{a}$ \\
\hline Nitossolo Vermelho Eutrófico típico (Oxisols) & Luzerna & $7.73 \mathrm{a}$ \\
\hline Nitossolo Bruno Distrófico típico (Oxisols & Painel & $7.72 \mathrm{a}$ \\
\hline Nitossolo Bruno Distroférrico típico (Oxisols) & Água Doce & $7.50 \mathrm{a}$ \\
\hline Argissolo Vermelho Distrófico abruptico (Ultisols) & Içara & $7.49 \mathrm{a}$ \\
\hline Chernossolo Argilúvico Férrico típico (---) & Descanso & $6.97 \mathrm{a}$ \\
\hline Argissolo Vermelho-Amarelo Alumínico típico (Ultisols) & Gaspar & $5.84 \mathrm{a}$ \\
\hline Argissolo Vermelho Distrófico abruptico (Ultisols) & Içara & $5.36 \mathrm{a}$ \\
\hline Neossolo Regolítico Húmico típico (Entisols) & Lages & $5.06 \mathrm{a}$ \\
\hline Cambissolo Háplico Alumínico típico (Inceptisols) & Palmeira & $3.73 \mathrm{~b}$ \\
\hline Argissolo Amarelo Alítico típico (Ultisols) & Botuverá & $2.84 \mathrm{~b}$ \\
\hline Argissolo Amarelo Distrófico típico (Ultisols) & Rancho Queimado & $2.77 \mathrm{~b}$ \\
\hline Argissolo Vermelho-Amarelo Distrófico latossólico (Ultisols) & Lauro Müller & $2.71 \mathrm{~b}$ \\
\hline Argissolo Vermelho-Amarelo Alumínico típico (Ultisols) & Blumenau & $2.10 \mathrm{~b}$ \\
\hline Argissolo Vermelho-Amarelo Distrófico latossólico (Ultisols) & Lauro Müller & $1.73 \mathrm{~b}$ \\
\hline Neossolo Regolítico Eutrófico típico (Entisols) & Sangão & $1.42 \mathrm{~b}$ \\
\hline Cambissolo Háplico Alumínico úmbrico (Inceptisols) & Lages & $1.14 \mathrm{~b}$ \\
\hline Neossolo Quartzarênico Órtico típico (Inceptisols) & Araranguá & $1.12 \mathrm{~b}$ \\
\hline Neossolo Quartzarênico Órtico típico (Inceptisols) & Imbituba & $0.56 \mathrm{~b}$ \\
\hline
\end{tabular}


Such discrepant contents as those obtained in the present study $\left(26.59-0.56 \mathrm{mg} \mathrm{kg}^{-1}\right)$ may indicate the need for standardizing more than one quality reference value (QRV), thus reducing the possibility of classifying natural contents as contamination or allowing soils with very low contents to be contaminated. VRQs can be split into groups with different clay and/or iron oxide contents, since this study (Table 6), as well as several others (Campos et al., 2013, De Menezes et al., 2020, Almeida et al., 2020), found positive correlation between arsenic content and those said attributes.

Table 6. Pearson's correlation (r) between As content and soil attributes. Values of $\mathrm{p}<0.05$ means significant correlation.

\begin{tabular}{cccccccccc}
\hline & Silt & Clay & $\mathrm{CO}$ & $\mathrm{pH} \mathrm{H} \mathrm{H}_{2} \mathrm{O}$ & $\mathrm{T}$ value & $\mathrm{SB}$ & $\mathrm{V}$ & $\mathrm{Al}_{2} \mathrm{O}_{3}$ & $\mathrm{Fe}_{2} \mathrm{O}_{3}$ \\
\hline $\mathrm{r}$ & 0.32 & $\mathbf{0 . 6 1}$ & $\mathbf{0 . 4 6}$ & 0.04 & 0.34 & 0.29 & 0.05 & 0.23 & $\mathbf{0 . 6 0}$ \\
$\mathrm{p}$ & 0.08 & $\mathbf{0 . 0 0}$ & $\mathbf{0 . 0 1}$ & 0.82 & 0.08 & 0.12 & 0.80 & 0.21 & $\mathbf{0 . 0 0}$ \\
\hline
\end{tabular}

$\mathrm{CO}=$ organic carbon by the Walkley-Black method, total organic carbon; $\mathrm{T}$ value $=\mathrm{CEC}$ at $\mathrm{pH} 7.0 ; \mathrm{SB}=$ Sum of bases; $\mathrm{V}=$ Base saturation; $\mathrm{Al}_{2} \mathrm{O}_{3}$ and $\mathrm{Fe}_{2} \mathrm{O}_{3}$ obtained by sulfuric attack.

Source: Author's own production, 2020.

\section{CONCLUSIONS}

The difference in As content is due to the different genealogical formations of Santa Catarina soils. Effusive mafic rocks, as well as basic and intermediate magmatic ones, had the highest As content in comparison to the other parent materials.

Concerning soil class, different As content was found in the following descending sequence: Latossolos, according to EMBRAPA (Oxisols according to Soil Taxonomy) > Nitossolo (Ultisols, Oxisols (Kandic), Alfisols) $>$ Chernossolos (---) $=$ Cambissolo (Inceptisols) $=$ Argissolo (Ultisols) $>$ Neossolos (Entisols). Both the "Latossolo Vermelho Distrófico retrático úmbrico" (Oxisols) from Campos Novos and the "Nitossolo Vermelho Eutroférrico típico" (Oxisols) from Luzerna presented natural As contents above the prevention value established by the CONAMA 420 resolution (Conama, 2009).

There was positive correlation between the clay content and iron oxide and the natural As content.

\section{ACKNOWLEDGEMENTS}

We would like to thank the Programa de Apoio à Pesquisa (PAP) UDESC-FAPESC for financing the study.

\section{REFERENCES}

ATSDR. Arsenic is a naturally occurring element that is widely distributed in the Earth's crust. $2015 . \quad$ Available at https://www.atsdr.cdc.gov/sites/toxzine/arsenic_toxzine.html\#health_effects Access: 16 Aug. 2021.

ALMEIDA, C. C. et al. Adsorption and desorption of arsenic and its immobilization in soils. Scientia Agricola, v. 78, n. 3, p. 1-11, 2020.

ALMEIDA, J. A.; TORRENT, J.; BARRON, V. Cor de solo, formas do fósforo e adsorção de fosfatos em Latossolos desenvolvidos de basalto do extremo-sul do Brasil. Revista Brasileira de Ciência do Solo, v. 27, n. 6, p. 985-1002, 2003. 
ALONSO, D. L.; LATORRE, S.; CASTILlO, E.; BRANDÃO, P. F. B. Environmental occurrence of arsenic in Colombia: A review. Environmental Pollution, v. 186, p. 272281, 2014. http://dx.doi.org/10.1016/j.envpol.2013.12.009

ALVES, R. H.; RIETZLER, A. C. Efeitos tóxicos de arsênio em eisenia andrei em exposição a solos do entorno de minerações de ouro. Revista Brasileira de Ciencia do Solo, v. 39, n. 3, p. 682-691, 2015.

BOTSOU, F.; SUNGUR, A.; KELEPERTZIS, E.; SOYLAK, M. Insights into the chemical partitioning of trace metals in roadside and off- road agricultural soils along two major highways in Attica's region, Greece. Ecotoxicology and Environmental Safety, v. 132, p. 101-110, 2016. https://doi.org/10.1016/j.ecoenv.2016.05.032

BRINGHENTI, I.; ALMEIDA, J. A. DE; HOFER, A. Mineralogia e gênese de argissolos das Serras do Tabuleiro/Itajaí, Estado de Santa Catarina. Revista Brasileira de Ciência do Solo, v. 36, n. 4, p. 1057-1072, 2012.

CAMPOS, M. L.; GUILHERME, L. R. G.; LOPES, R. S.; ANTUNES, A. S.; MARQUES, J. J G. S.M.; CURI, N. Teor e capacidade máxima de adsorção de arsênio em Latossolos brasileiros. Revista Brasileira de Ciência do Solo, v. 31, n.6, p. 1311-1318, 2007.

CAMPOS, M. L.; GUILHERME, L. R. G.; LOPES, R. S.; MARQUES, J. J G. S. M.; CURI, N.; ARAUJO, A. S. A.; MIQULlUTI, D. J.; LOPES, C.; SPIAZZI, F. R. Teores de arsênio e cádmio em solos do bioma Cerrado. Revista Brasileira de Ciência do Solo, v. 37, n. 1, p. 281-286, 2013.

CHIRENJE, T.; MA, L. Q.; CHEN, M.; ZILLIOUX, E. J. Comparison between background concentrations of arsenic In urban and non-urban areas of Florida. Advances in Environmental Research, v. 8, p. 137-146, 2003. http://dx.doi.org/10.1016/s10930191(02)00138-7

CONAMA (Brasil). Resolução no 420 de 28 de dezembro de 2009. Dispõe sobre critérios e valores orientadores de qualidade do solo quanto à presença de substâncias químicas e estabelece diretrizes para o gerenciamento ambiental de áreas contaminadas por essas substâncias em decorrência de atividades antrópicas. Diário Oficial [da] União: seção 1, Brasília, DF, n. 249, p. 81-84, 30 dez. 2009.

CORRÊA, J. Mineralogia e gênese das principais classes de solos de encostas basálticas do estado de Santa Catarina. Lages. 2003. 141p. Dissertação (Mestrado) - Universidade do Estado de Santa Catarina, Florianópolis, 2003.

DA COSTA, A.; AlBUQUERQUE, J. A.; ALMEIDA, J. A.; DA COSTA, A.; LUCIANO, R. V. Pedotransfer functions to estimate retention and availability of water in soils of the state of Santa Catarina, Brazil. Revista Brasileira de Ciência do Solo, v. 37, n. 4, p. 889910, 2013.

CURI, N.; FRANZMEIER, D. P. Effect of Parent Rocks on Chemical and Mineralogical Properties of Some Oxisols in Brazil. Soil Science Society of America Journal, v. 51, n. 1, p. 153-158, 1987.

DE MAGALHÃES, V. F.; PFEIFFER, W. C. Arsenic concentration in sediments near a metallurgical plant (Sepetiba Bay, Rio de Janeiro, Brazil). Journal of Geochemical Exploration, v. 52, n. 1-2, p. 175-181, 1995. 
DE MENEZES, M. D.; BISPO, F. H. A.; FARIA, W. M.; GONÇALVES, M. G. M.; CURI, N.; GUIHLERME, L, R, G. Modeling arsenic content in Brazilian soils: What is relevant? Science of the Total Environment, p. 58, 2020.

DE SOUZA, L. C.; CAMPOS, M. L; REICHERT, G.; MOURA, C. N.; Teores de Arsênio em solos de três regiões do estado de Santa Catarina. Revista Ambiente \& Agua, v. 11, n. 1, p. 445- 458, 2016.

GAO, W.; NI, W.; ZHANG, Y.; LI, Y.; SHI, T.; LI, Z. Investigation into the semi-dynamic leaching characteristics of arsenic and antimony from solidified / stabilized tailings using metallurgical slag-based binders. Journal of Hazardous Materials, v. 381, p. 120992, 2020. https://doi.org/10.1016/j.jhazmat.2019.120992

GOLDSCHMIDT, V. M. Geochemistry. Londres: Oxford University Press, 1958. 425 p.

GONG, Y.; QU, Y.; YANG, S.; TAO, S.; LIU, Q.; CHEN, Y.; WU, Y.; MA, J. Status of arsenic accumulation in agricultural soils across China (1985-2016). Environmental Research, v. 186, p. 109525, 2020. https://doi.org/10.1016/j.envres.2020.109525

HAYES, K. F.; TRAINA, S. J. Metal speciation and its significance in ecosystem health. In: HUANG, P. M. Soil chemistry and ecosystem health. Madison: Soil Science Society of America Journal, p. 45-84, 1998.

LUNARDI NETO, A.; ALMEIDA, J. A. de. Mineralogia das frações silte e argila em Argissolos com horizontes subsuperficiais escurecidos em Santa Catarina. Revista de Ciências Agroveterinárias, v. 12, n. 3, p. 282-293, 2013.

MANDAL, B. K.; SUZUKI, K. T. Arsenic round the world: a review. Talanta, v. 58, p. 201235, 2002.

MANDAL, P. An insight of environmental contamination of arsenic on animal health. $\begin{array}{llllllll}\text { Emerging } & \text { Contaminants, } & \text { v. } 3, \quad \text { n. } & \text { 2, } & \text { p. }\end{array}$ http://dx.doi.org/10.1016/j.emcon.2017.01.004

MARRUGO-NEGRETE, J.; PINEDO-HERNÁNDEZ, J.; DÍEZ, S. Assessment of heavy metal pollution, spatial distribution and origin in agricultural soils along the Sinú River Basin, Colombia. Environmental Research, v. 154, p. 380-388, 2017.

MCBRIDE, M. B. Environmental chemistry of soils. New York: Oxford University Press, 1994. $406 \mathrm{p}$.

MIRLEAN, N.; ROISENBERG, A. The effect of emissions of fertilizer production on the environment contamination by cadmium and arsenic in southern Brazil. Environmental Pollution, v. 143, n. 2, p. 335-340, 2006.

PAES SOBRINHO, J. B.; ALMEIDA, J. A.; ERHART, J. Mineralogia, propriedades químicas e classificação de solos das Serras do Leste Catarinense. Revista de Ciências Agroveterinárias, v. 8, n. 1, p. 9-24, 2009.

PAYE, H. S.; MELLO, J. W. V.; ABRAHÃO, W. A. P.; FERNANDES FILHO, E. I.; DIAS, L. C. P.; CASTRO, M. L. O. et al. Valores de referência de qualidade para metais pesados em solos no estado do Espírito Santo. Revista Brasileira de Ciência do Solo, v. 34, p. 2041-2051, 2010. 
PEREIRA, S. DE F. P.; OLIVEIRA, G. R. F.; OLIVEIRA, J. S.; SILVA, J. S.; SOUZA JUNIOR, P. M.; Determinação espectrofotométrica do arsênio em solo da cidade de Santana-AP usando o método do dietilditiocarbamato de prata (SDDC) modificado. Acta Amazonica, v. 39, n. 4, p. 953-960, 2009.

QIAO, P.; YANG, S.; LEI, M.; CHEN, T.; DONG, N. Quantitative analysis of the factors influencing spatial distribution of soil heavy metals based on geographical detector. Elsevier, v. 664, p. 392-413, 2019. https://doi.org/10.1016/j.scitotenv.2019.01.310

R CORE TEAM. R: A language and environment for statistical computing. Vienna, 2016. https://www.R-project.org/.

REIMANN, C.; MATSCHULLAT, J.; BIRKE, M.; SALMINEN, R. Arsenic distribution in the environment: The effects of scale. Applied Geochemistry, v. 24, p. 1147-1167, 2009.

ROSAS, C, J. M.; GUZMÁN, M, J. L.; HERNÁNDEZ, R, A.; GARZAGONZÁLEZ, M. T.; HINOJOSA, R, L. Arsenic accumulation in maize crop (Zea mays): A review. Science of the Total Environment, v. 488-489, p. 176-187, 2014. http://dx.doi.org/10.1016/j.scitotenv.2014.04.075

ROY, M.; GIRI, A. K.; DUTTA, S.; MUKHERJEE, P. Integrated phytobial remediation for sustainable management of arsenic in soil and water. Environment International, v. 75, p. 180-198, 2015. http://dx.doi.org/10.1016/j.envint.2014.11.010

SINGH, R.; SINGH, S.; PARIHAR, P.; SINGH, V. P.; PRASAD, S. M. Arsenic contamination, consequences and remediation techniques: a review. Ecotoxicology and Environmental Safety, v. 112, p. 247-270, 2015. http://dx.doi.org/10.1016/j.ecoenv.2014.10.009

SU, Y.; YANG, R. Background concentrations of elements in surface soils and their changes as affected by agriculture use in the desert-oasis ecotone in the middle of Heihe River Basin, North-west China. Journal of Geochemical Exploration, v. 98, p. 57-64, 2008. http://dx.doi.org/10.1016/j.gexplo.2007.12.001

TARVAINEN, T.; ALBANESE, S.; BIRKE, M.; PONAVIC, M.; REIMANN, C. Arsenic in agricultural and grazing land soils of Europe. Applied Geochemistry, v. 28, p. 2-10, 2013. http://dx.doi.org/10.1016/j.apgeochem.2012.10.005

TESKE, R.; ALMEIDA, J. A.; HOFFER, A.; LUNARDI NETO, A. Caracterização química, física e morfológica de solos derivados de rochas efusivas no Planalto Sul de Santa Catarina, Brasil. Revista de Ciências Agroveterinárias, v. 12, n. 2, p. 175-186, 2013.

TSUJI, J. S.; YOST, L. J.; BARRAJ, L. M, SCRAFFORD, C. G.; MINK, P. J. Use of background inorganic arsenic exposures to provide perspective on risk assessment results. Regulatory Toxicology and Pharmacology, v. 48, p. 59-68, 2007. http://dx.doi.org/10.1016/j.yrtph.2007.01.004

VAREJÃO, E. V. V.; BELLATO, C. R.; MELO, J. W. V.; FONTES, M. P. F. Optimization of pre-reduction conditions of As(v) in bcr extracts to quantify arsenic by HG-AAS. Revista Brasileira de Ciência do Solo, n. 33, p. 875-883, 2009.

XU, Y.; WANG, K.; ZHOU, Q.; ZHANG, L.; QIAN, G.; Effects of humus on the mobility of arsenic in tailing soil and the thiol- modification of humus. Chemosphere, v. 259, p. 127403, 2020. https://doi.org/10.1016/j.chemosphere.2020.127403

WHO. Health impacts of chemicals arsenic. 2018. Available at: https://www.who.int/en/news-room/fact-sheets/detail/arsenic Access: 16 Aug. 2021. 